\title{
PENGARUH IKLIM KERJA TERHADAP KINERJA GURU PADA MADRASAH ALIYAH DI KECAMATAN GANTARANG KABUPATEN BULUKUMBA
}

\author{
HAMSAH, ST. SYAMSUDDUHA, ULFIANI RAHMAN \\ Pascasarjana Universitas Islam Negeri Alauddin Makassar \\ Email: hamsahmpi@gmail.com
}

\begin{abstract}
:
This study aims to: 1) find out the description of the work climate at Madrasah Aliyah in Gantarang District, Bulukumba Regency; 2) find out the reality of teachers' performance at Madrasah Aliyah in Gantarang District, Bulukumba Regency; 3) determine the effect of the work climate on teachers' performance at Madrasah Aliyah in Gantarang District, Bulukumba Regency. This type of research is an ex post facto research as part of quantitative research. Respondents in this study were 75 teachers taken as a whole at Madrasah Aliyah in Gantarang District, Bulukumba Regency. Data collection techniques used are the scale of work climate, the scale of teachers' performance and documentation, while the data analysis technique used is descriptive and inferential statistical analysis with hypothesis testing using simple linear regression analysis. Indicators of work climate tested for their effect on teacher performance include: trust in subordinates; openness in communicating environmental conditions; leadership that helps and appreciates; joint problem solving; teacher autonomy; kinship; being indifferent; authoritarian leadership; and low employee morale. While the indicators tested on teacher performance include: planning of learning activities programs, implementing learning activities and evaluating / evaluating learning. The results of this study indicate that the work climate has a positive effect on teachers' performance with a coefficient of determination of 0.382. Thus, the magnitude of the influence of the work climate on teacher performance in Madrasah Aliyah in Gantarang District, Bulukumba Regency is $38.2 \%$ and $61.8 \%$ is determined by other factors.
\end{abstract}

Keywords: Work Climate, Teacher Performance, Madrasah Aliyah

\section{PENDAHULUAN}

$P$ eningkatan mutu pendidikan merupakan sasaran pembangunan di bidang pendidikan nasional dan menjadi bagian integral dari peningkatan kualitas manusia Indonesia secara kaffah (menyeluruh). Upaya mencerdaskan bangsa menjadi tanggung jawab pendidikan terutama dalam mempersiapkan peserta didik menjadi subjek yang bertakwa kepada Tuhan Yang Maha Esa, berakhlak mulia, tangguh, kreatif, mandiri, demokratis dan profesional dibidangnya masing-masing.

Madrasah maupun sekolah umum sebagai lembaga pendidikan diselenggarakan dalam rangka mempersiapkan generasi pelopor untuk mewujudkan cita-cita bangsa. Karena itu, Iulusan bermutu, berkualitas dan berkepribadian luhur 
haruslah dihasilkan melalui proses pendidikan baik di madrasah maupun sekolah umum.

Mengingat mengajar pada hakikatnya merupakan upaya guru dalam menciptakan situasi belajar, maka metode yang digunakan oleh guru bisa menumbuhkan berbagai kegiatan belajar bagi pelajar sehubungan dengan kegiatan mengajar guru. Proses pembelajaran merupakan proses interaksi edukatif antara guru yang menciptakan suasana belajar dan pelajar yang memberi respons terhadap usaha guru tersebut.

Upaya guru dalam memilih metode yang baik merupakan upaya mempertinggi mutu pengajaran atau pendidikan yang menjadi tanggung jawabnya. Terkait dengan metode tersebut, maka guru sebaiknya memiliki wawasan keilmuan, termasuk memahami suasana bekerja, belajar, berkomunikasi, dan bergaul dalam proses pembelajaran. Hal tersebut mengisyaratkan bahwa guru hendaknya menciptakan iklim kerja yang baik.

Iklim kerja di sekolah didefinisikan sebagai seperangkat atribut yang memberi warna atau karakter, spirit, etos, suasana batin, dari setiap sekolah (Fiser, 2010:1). Iklim kerja menggambarkan suasana dan hubungan kerja antara sesama guru, antara guru dengan kepala sekolah, antara guru dengan tenaga kependidikan lainnya serta antar dinas dilingkungannya, hal ini merupakan wujud dari lingkungan kerja yang kondusif.

Supardi (2015:208) menyatakan bahwa Iklim sekolah yang kondusif dapat mempengaruhi kinerja guru dalam suatu sekolah yang dapat berupa iklim kerja fisik dan non-fisik. Lebih lanjut, Burhanudin (2007:1) mengungkapkan bahwa kinerja guru adalah gambaran kualitas kerja yang dimiliki guru dan termanifestasi melalui penguasaan dan aplikasi atas kompetensi guru. Kinerja guru mempunyai spesifikasi tertentu, kinerja guru dapat dilihat dan diukur berdasarkan spesifikasi atau kriteria kompetensi yang harus dimiliki oleh setiap guru.

Salah satu faktor yang menjadi tolak ukur keberhasilan pendidikan di sekolah adalah kinerja guru, karena guru merupakan salah seorang pelaksana pendidikan yang sangat diperlukan. Akan tetapi, tidak jarang ditemukan guru yang kurang memiliki gairah dalam melaksanakan tugasnya, baik dari segi merencanakan pembelajaran, melaksanakan pembelajaran, maupun dalam mengevaluasi pembelajaran yang tentu akan berdampak terhadap kurang berhasilnya tujuan yang hendak dicapai.

Pencapaian kinerja seorang guru yang baik dan berkualitas merupakan sesuatu yang sangat diharapkan baik oleh pribadi pekerja ataupun lembaga pendidikan, karena dengan kinerja yang baik sebagi bukti bahwa kinerja tersebut profesional, dan untuk mencapai kinerja yang baik dipengaruhi oleh faktor diri sendiri atau kemampuan dan faktor lingkungan atau motivasi. Oleh karenanya, dapat dikatakan bahwa faktor yang mempengaruhi pencapaian kinerja dapat dilihat dari faktor kemampuan (ability) dan faktor motivasi (motivation). 
Hal ini sesuai dengan pendapat Davis dalam Mangkunegara (2008:67) yang merumuskan, ada tiga faktor yang mempengaruhi kinerja yaitu: (1) Human Performance $($ penampilan kerja) $=$ ability + motivation; (2) Motivation $=$ attitude + situation; dan (3) Ability (kemampuan potensi diri) = knowledge + skill (kemampuan reality).

Permasalahan yang ditemukan di Madrasah Aliyah se-Kecamatan Gantarang tentang kinerja guru, masih ditemukan kinerja guru belum optimal. Hal tersebut terlihat dari indikasi sebagai berikut: (1) guru cenderung mempersiapkan perangkat pembelajaran hanya ketika akan disupervisi, sehingga pada proses pembelajaran tampak kurang menguasai materi karena tidak mempersiapkan diri secara optimal sebelum mengajar; (2) metode pembelajaran tradisional masih mendominasi dalam proses pembelajaran, sehingga pembelajaran kurang efektif; (3) jarang memeriksa tugas-tugas maupun hasil ulangan; (4) minimnya keinginan untuk meningkatkan kemampuan dalam bentuk pelatihan. Permasalahan tersebut terkait dengan kurangnya motivasi kerja yang dimiliki oleh guru. Apabila permasalahan tersebut dibiarkan berlanjut, akan berdampak pada mutu madrasah. Berdasarkan permasalahan tersebut, penelitian ini dilakukan dengan tujuan untuk menganalisis pengaruh iklim kerja terhadap kinerja guru pada Madrasah Aliyah di Kecamatan Gantarang Kabupaten Bulukumba.

\section{METODE PENELITIAN}

Pendekatan penelitian ini adalah pendekatan kuantitatif dengan metode ex post facto, yaitu penelitian empiris yang sistematis dimana ilmuwan tidak mengendalikan variabel bebas secara langsung karena variabel tersebut tidak dapat dimanipulasi. Kesimpulan tentang adanya hubungan diantara variabel tersebut dibuat berdasarkan perbedaan yang mengiringi variabel bebas dan variabel terikat, tanpa intervensi langsung.

Penelitian ini dilaksanakan pada Madrasah Aliyah di Kecamatan Gantarang Kabupaten Bulukumba. Responden dalam penelitian ini sebanyak 75 orang guru yang diambil secara keseluruhan. Teknik pengumpulan data yang digunakan adalah angket kemudian dianalisis dengan menggunakan analisis regresi linear sederhana untuk menguji hipotesis.

\section{HASIL PENELITIAN DAN PEMBAHASAN}

Deskripsi Iklim Kerja pada Madrasah Aliyah di Kecamatan Gantarang Kabupaten Bulukumba

Data hasil penelitian terkait variabel iklim kerja yang diperoleh pada Madrasah Aliyah di Kecamatan Gantarang Kabupaten Bulukumba melalui angket dengan jumlah responden sebanyak 75 orang dapat dianalisis secara deskriptif. Data yang 
diperoleh dari penelitian ini yaitu range sebesar 20, data maksimum sebesar 111 dan data minimumnya adalah 91.

Realitas iklim kerja pada Madrasah Aliyah di Kecamatan Gantarang Kabupaten Bulukumba dapat diketahui dengan menginterpretasikan mean score yang diperoleh, yaitu 99,91. Nilai 99,91 berada pada interval 89-109 dengan jumlah frekuensi sebanyak 74 orang dan persentase sebesar $98,67 \%$ yang menandakan bahwa iklim kerja tersebut berada pada kategori tinggi sebagaimana interpretasi data pada tabel berikut:

Tabel 1. Interpretasi Kategori Iklim Kerja

\begin{tabular}{c|c|c|c}
\hline Interval & Kategori & Frekuensi & Persentase \\
\hline $26-46$ & Sangat rendah & 0 & $0 \%$ \\
$47-67$ & Rendah & 0 & $0 \%$ \\
$68-88$ & Cukup & 0 & $0 \%$ \\
$89-109$ & Tinggi & 74 & $98,67 \%$ \\
$110-130$ & Sangat tinggi & 1 & $1,33 \%$ \\
\hline Jumlah & - & 75 & $100 \%$ \\
\hline
\end{tabular}

Sumber: Data diolah, 2019 (Output SPSS21)

Tabel 1 dibuat dengan ketentuan bahwa skor kriterium tiap item adalah 130 karena jumlah item pernyataan $=26$, jumlah alternatif pada setiap pernyataan $=5$, sehingga nilai ideal $=130$ dan nilai terendah yang mungkin diperoleh $=26$. Tabel konversi nilai dibuat dengan ketentuan jumlah kelas $=5$ (sesuai jumlah alternatif setiap pernyataan) dan interval kelas $=130-26 / 5=20,8$ (dibulatkan menjadi 21).

Hasil analisis statistik deskriptif menunjukkan bahwa rata-rata tanggapan dari 75 responden terkait iklim kerja pada Madrasah Aliyah di Kecamatan Gantarang Kabupaten Bulukumba sebesar 99,91. Hasil interpretasi dengan menggunakan garis kontinum juga menunjukkan bahwa iklim kerja berada pada daerah tinggi. Nilai persentase iklim kerja berdasarkan hasil analisis $=99,91 / 130=0,768$. Dengan demikian, realitas iklim kerja 76,8\% dari kriteria yang ditetapkan (100\%). Oleh karena itu, iklim kerja pada Madrasah Aliyah di Kecamatan Gantarang Kabupaten Bulukumba sudah termasuk kondusif, tetapi masih terdapat 23,2\% yang perlu ditingkatkan agar menjadi optimal.

\section{Deskripsi Kinerja Guru pada Madrasah Aliyah di Kecamatan Gantarang Kabupaten Bulukumba}

Data hasil penelitian terkait variabel iklim kerjayang diperolehpada Madrasah Aliyah di Kecamatan Gantarang Kabupaten Bulukumba melalui angket dengan jumlah responden sebanyak 75 orangdapat dianalisis secaradeskriptif. Data yang diperoleh dari penelitian ini yaitu range sebesar 20, data maksimum sebesar 86 dan data minimumnya adalah 106.

Realitas kinerja guru pada Madrasah Aliyah di Kecamatan Gantarang Kabupaten Bulukumba dapat diketahui dengan menginterpretasikan mean score 
yang diperolehyaitu 95,84. Nilai 95.84 berada pada interval 86-105 dengan jumlah frekuensi sebanyak 74 orang dan persentase sebesar 98,67\% yang menandakan bahwa kinerja guru tersebut berada pada kategori tinggi sebagaimana interpretasi data pada Tabel 2.

Tabel 2 dibuat dengan ketentuan bahwa skor kriterium tiap item adalah 125 karena jumlah item pernyataan $=25$ sehingga nilai ideal $=125$ dan nilai terendah yang mungkin diperoleh $=25$. Tabel konversi nilai dibuat dengan ketentuan jumlah kelas $=5$ (sesuai jumlah alternatif setiap pernyataan) dan interval kelas $=125$ $25 / 5=20$.

Tabel 2. Interpretasi Kategori Kinerja Guru

\begin{tabular}{c|c|c|c}
\hline Interval & Kategori & Frekuensi & Persentase \\
\hline $25-45$ & Sangat rendah & 0 & $0 \%$ \\
$46-65$ & Rendah & 0 & $0 \%$ \\
$66-85$ & Cukup & 0 & $0 \%$ \\
$86-105$ & Tinggi & 74 & $98,67 \%$ \\
$106-125$ & Sangat tinggi & 1 & $1,33 \%$ \\
\hline Jumlah & - & 75 & $100 \%$ \\
\hline
\end{tabular}

Sumber: Data diolah, 2019 (Output SPSS22)

Hasil analisis statistik deskriptif menunjukkan bahwa rata-rata atau mean score tanggapan dari 75 responden terkait kinerja guru pada Madrasah Aliyah di Kecamatan Gantarang Kabupaten Bulukumba sebesar 95,84. Berdasarkan konversi nilai, rata-rata tanggapan tersebut berada pada interval 86-105 yang mengindikasikan bahwa kinerja guru termasuk pada kategori tinggi dengan jumlah frekuensi 74 orang dan persentase $98,67 \%$. Hasil interpretasi dengan menggunakan garis kontinum juga menunjukkan bahwa kinerja guru berada pada daerah tinggi. Nilai persentase kinerja guru berdasarkan hasil analisis $=95,84 / 125=0,767$. Dengan demikian, realitas kinerja guru 76,7\% dari kriteria yang ditetapkan (100\%). Oleh karena itu, kinerja guru pada Madrasah Aliyah di Kecamatan Gantarang Kabupaten Bulukumba sudah termasuk baik, tetapi masih terdapat 23,3\% yang perlu ditingkatkan agar menjadi optimal.

\section{Pengaruh Iklim Kerja Terhadap Kinerja Guru pada Madrasah Aliyah di Kecamatan Gantarang Kabupaten Bulukumba}

Pengujian hipotesis dilakukan dengan menggunakan analisis regresi linear sederhana untuk menguji hipotesis. Koefisien regresi digunakan untuk memprediksi perubahan nilai variabel dependen jika variabel independen dimanipulasi atau diubah-ubah dinaik turunkan. Hasil analisis regresi linear sederhana menunjukkan bahwa nilai Constant (a) sebesar 35,594 dan nilai koefisien regresi (b) sebesar 0,603 . Dengan demikian persamaan regresinya $Y=35,594+0,603 X$. Hal tersebut mengindikasikan bahwa jika iklim kerja $(X)$ naik satu satuan, kinerja guru $(Y)$ dapat diprediksikan meningkat sebesar 0,603 (60,3\%) pada konstanta 35,594. Dengan 
demikian hipotesis dapat diterima atau terbukti kebenarannya dengan ketentuan sebagai berikut:

$\mathrm{H}_{0}$ : Tidak terdapat pengaruh iklim kerja terhadap kinerja guru

$\mathrm{H}_{1}$ : Terdapat pengaruh iklim kerja terhadap kinerja guru

Ketentuan penerimaan atau penolakan Ho sebagai berikut:

Jika sig < a $(0,05)$, maka $\mathrm{H}_{0}$ ditolak dan $\mathrm{H}_{1}$ diterima

Jika sig > a $(0,05)$, maka $\mathrm{H}_{0}$ diterima dan $\mathrm{H}_{1}$ ditolak

Uji regresi berdasarkan Tabel Coefficient diperoleh nilai t sebesar 6,715 dengan nilai Sig. 0,000. Nilai Sig. 0,000 tersebut lebih kecil dari 0,05 yang mengindikasikan bahwa $\mathrm{H}_{0}$ ditolak dan $\mathrm{H}_{1}$ diterima. Dengan demikian iklim kerja berpengaruh terhadap kinerja guru pada Madrasah Aliyah di Kecamatan Gantarang Kabupaten Bulukumba.

Pengujian pengaruh iklim kerja terhadap kinerja guru pada Madrasah Aliyah di Kecamatan Gantarang Kabupaten Bulukumba dilakukan melalui analisis regresi linear sederhana. Iklim kerja yang diteliti memiliki 9 indikator, yaitu: percaya pada bawahan; keterbukaan dalam komunikasi; kepemimpinan yang menolong dan menghargai; pemecahan masalah bersama; otonomi guru; kekeluargaan; bersikap acuh tak acuh; kepemimpinan otoriter dan semangat kerja bawahan rendah.

Besarnya pengaruh iklim kerja terhadap kinerja guru dapat dilihat pada hasil uji determinansi. Hasil pengujian tersebut menunjukkan bahwa nilai koefisien determinansi sebesar 0,382. Dengan demikian, besarnya pengaruh iklim kerja terhadap kinerja guru pada Madrasah Aliyah di Kecamatan Gantarang Kabupaten Bulukumba adalah 38,2\% dan 61,8\% ditentukan oleh faktor lain.

Hasil pengujian hipotesis menunjukkan bahwa iklim kerja berpengaruh terhadap kinerja guru pada Madrasah Aliyah di Kecamatan Gantarang. Hal tersebut mengindikasikan bahwa tingginya kinerja guru ditentukan oleh iklim kerja yang kondusif. Dengan demikian, semakin kondusif iklim kerja yang tercipta di lingkungan madrasah, semakin tinggi pula kinerja guru yang dihasilkan. Oleh karena itu, kenyamanan yang dirasakan oleh guru di lingkungan madrasah akan memberikan motivasi kepada mereka untuk melaksanakan tugasnya yang bersifat rutin, yaitu melaksanakan kegiatan pembelajaran.

Iklim kerja yang kondusif akan menjadikan lingkungan madrasah menjadi nyaman sehingga akan menjadi salah satu pendorong bagi guru untuk melaksanakan tugasnya dengan baik. Hal ini sebagaimana dikemukakan oleh Supardi (2015: 208) bahwa salah satu aspek penting yang mendukung keberhasilan proses pembelajaran adalah iklim madrasah.

Hal tersebut sejalan dari hasil penelitian Hasana (2010) yang membuktikan bahwa iklim kerja berpengaruh terhadap kinerja guru. Sedangkan Khoirunnisa (2014) dalam penelitiannya juga membuktikan bahwa iklim kerja berpengaruh terhadap kinerja pegawai, semakin baik iklim kerja, semakin berpengaruh positif terhadap kinerja pegawai. Hal ini mengindikasikan bahwa pengaruh iklim kerja 
terhadap kinerja tidak hanya ditemukan pada lembaga pendidikan, tetapi juga pada organisasi umum.

Hasil penelitian ini juga memperkuat temuan Ridwan (2013) yang menemukan bahwa iklim kerja di suatu sekolah sangat berpengaruh terhadap tingkah laku guru dan pegawai lainnya. Uraian tersebut menjelaskan bahwa dalam proses pengendalian iklim kerja sekolah, peran kunci ada di kepala sekolah dengan dukungan para guru dan stafnya.

Sawianti (2019) dalam penelitiannya membuktikan bahwa iklim sekolah berpengaruh positif terhadap kinerja guru. Dengan demikian, hasil penelitian Sawianti didukung oleh hasil penelitian ini yang sama-sama membuktikan adanya pengaruh iklim kerja di madrasah terhadap kemampuan guru dalam berkinerja. Temuan ini juga mendukung hasil penelitian Sumarsono (2012) yang membuktikan iklim sekolah berhubungan signifikan dengan kinerja guru yang menandakan bahwa peningkatan iklim sekolah akan mengakibatkan peningkatan tingkat kinerja guru. Lebih lanjut, Hamid (2014) dalam penelitiannya juga membuktikan bahwa iklim kerja memiliki pengaruh yang signifikan terhadap kinerja guru.

Hasil penelitian ini telah mendukung hasil-hasil penelitian sebelumnya sehingga memberikan pemahaman bahwa iklim kerja yang tercipta dengan kondusif dapat menjadi faktor pendukung sehingga memberi pengaruh positif terhadap peningkatan kinerja guru. Hal ini menunjukkan bahwa tinggi rendahnya kinerja guru, ada hubungannya dengan kondusif atau tidaknya iklim kerja yang ada pada lingkungan madrasah. Dengan demikian, kinerja guru dipengaruhi oleh iklim kerja yang kondusif.

\section{PENUTUP/SIMPULAN}

Berdasarkan hasil analisis data dan pembahasan dapat disimpulkan bahwa iklim kerja pada Madrasah Aliyah di Kecamatan Gantarang Kabupaten Bulukumba berada pada kategori tinggi dengan persentase 76,8\% yang menandakan bahwa iklim kerja tersebut termasuk kondusif. Kinerja guru pada Madrasah Aliyah di Kecamatan Gantarang Kabupaten Bulukumba berada pada kategori tinggi dengan persentase $76,7 \%$ yang menandakan bahwa kinerja guru sudah termasuk baik. Iklim kerjapada Madrasah Aliyah di Kecamatan Gantarang Kabupaten Bulukumba berpengaruh positif terhadap kinerja guru dengan koefisien determinansi sebesar 0,382 sehingga kinerja guru $38,2 \%$ ditentukan oleh iklim kerja dan $61,8 \%$ ditentukan oleh faktor lain.

\section{DAFTAR PUSTAKA}

Burhanudin. (2007). Analisis Administrasi Manajemen dan Kepemimpinan Pendidikan. Bumi Aksara: Jakarta.

Fiser. (2010). Motivasi dan Iklim Lingkungan Kerja Sekolah. 
Hamid, Abdul. (2014). Pengaruh Iklim Kerja terhadap Kinerja Guru Madrasah Ibtidaiyah Negeri Kota Bandar Lampung, Jurnal Al Bayan: Jurnal Jurusan Pendidikan Bahasa Arab, 6(2).

Hasana, Dedeh Sofia. (2010). Pengaruh Pendidikan Latihan (Diklat) Kepemimpinan Guru dan Iklim Kerja terhadap Kinerja Guru Sekolah Dasar se-Kecamatan Babakancikao Kabupaten Purwakarta, Jurnal Penelitian Pendidikan, 11(2).

Khoirunnisa, Fauziyah Novia. (2014). Pengaruh Disiplin Kerja dan Iklim Kerja terhadap Kinerja Guru Ekonomi/Akuntansi di SMA Negeri se-Kabupaten Wonosobo, Economic Education Analysis Journal, 4(1).

Mangkunegara. (2008). Manajemen Sumber Daya Perusahaan. Bandung: Rosdakarya.

Ridwan, Moh. (2013). Pengaruh Iklim Kerja dan Budaya Sekolah terhadap Kinerja Guru (Studi pada MA di Kabupaten Cilacap), Jurnal IImiah Mahasiswa Pascasarjana Administrasi Pendidikan, 1(2).

Sawianti, IImi. (2019). Pengaruh Iklim Sekolah terhadap Kinerja Guru di SMP Negeri 1 Ulaweng Kabupaten Bone, Journal of Islamic Education Management, 5(1).

Sumarsono, Raden Bambang. (2012). Iklim Sekolah, Komitmen Organisasi, Kepuasan Kerja, dan Kinerja Guru, JurnalManajemen Pendidikan, 23(6).

Supardi. (2015). Sekolah Efektif: Konsep Dasar dan Praktiknya. Cet. II. Jakarta: Raja Grafindo Persada. 